\title{
Development and experimental study of circuits of contactless device for automation of compensation of reactive power of capacitor batteries
}

\author{
Maxsud K. Bobojanov ${ }^{1}$, Raxmatillo Ch. Karimov ${ }^{l}$, Toir H. Qosimov ${ }^{1}$, Shokhin Dzh. Dzhuraev² \\ ${ }^{1}$ Tashkent state technical university named after Islam Karimov, Tashkent, Uzbekistan \\ ${ }^{2}$ Tajik technical university named after academic M.S.Osimi, Dushanbe, Tajikistan
}

\begin{abstract}
This article presents material based on the results of the analysis of literature sources on automatic devices for regulating reactive power in power supply systems. The operating mode of the compensating devices is determined taking into account the permissible voltage deviations at the terminals of the electric power receivers. Voltage, load current, reactive power directions, power factor, phase angle between the supply voltage and load current, and time can be used as control parameters. In addition, the article provides information regarding the performance of the developed circuits of contactless devices and verification of the experimental study of the operation of installations with their use. Also presented is material on the experimental study of a prototype of a contactless switching device for automatic power control of capacitor banks in various operating modes. Summarizing the results of experimental studies of a new device for automatic power control of capacitor banks, it can be stated that it fully meets the requirements for such devices and can ensure reliable operation of the power supply network with an appropriate power factor.
\end{abstract}

\section{Introduction}

Improving the reliability of power supply systems, developing and implementing energy-saving technologies and ways to reduce electricity losses is one of the topical issues of today. The reliability of the power supply system is associated with the safe implementation of switching in the system by turning on, off, transferring power to consumers. The efficiency of the power supply system is influenced by many factors, one of the main among them is the optimal start-up, regulation of the power of capacitor units [1-4].

Ensuring the economical operation of capacitor units is possible by regulating their power when changing the magnitude and nature of the loads, depending on the voltage at the point of connection of the capacitors [3-5].

Non-contact devices for switching and regulating the power of capacitor units are distinguished by their speed, long service life, quiet operation and other advantages [2-6].

In recent years, reactive power compensation devices with automatic control have been introduced in the power supply systems of large industrial and commercial consumers. The main reason for this application was the need to maintain the mains voltage at an acceptable level and compensate for reactive power to reduce losses in medium voltage distribution networks [4-7].

\footnotetext{
${ }^{*}$ Corresponding author
}

E-mail: raxmatillo82@mail.ru, dzhuraevsh@mail.ru
To ensure the most economical operating modes of power supply systems, power control of compensating devices is used. The regulation of the reactive power generated by the capacitors can be carried out in steps by dividing the batteries into parts The greater the number of such steps, the more perfect the regulation, but the greater the capital cost of installing switches and protective equipment [6-8].

The operating mode of the compensating devices is determined taking into account the permissible voltage deviations at the terminals of the electric power receivers [9]. Voltage, load current, reactive power directions, power factor, phase angle between the supply voltage and load current, and time can be used as control parameters [7-10].

\section{Requirements for reactive power compensation in an industrial enterprise}

The power control of the voltage compensating devices is carried out depending on the voltage deviation. In this case, the control of the compensating devices must be coordinated with the regulation of the voltage value by other means $[1,9$ 12].

The simplest way is time management. In this case, the operating mode of the power supply system must be studied in advance [11-13].

According to the daily schedule of reactive power consumption, it should be determined that one part of the capacitor banks is switched on continuously for 24 hours, and 
the second is switched on according to the load schedule only for a certain time $t_{1}$ [10-12].

Stepwise regulation of the power of capacitor banks leads to a significant complication of control circuits, therefore, for voltages up to $1000 \mathrm{~V}$, it is recommended to use complete capacitor units with a single power of $75,100,150,200,250$, $300 \mathrm{kVar}$ per unit, and at a voltage of $6-10 \mathrm{kV}$ - complete capacitor units with a single power of 300, 450, 600, 750, 900, 1050, $1200 \mathrm{kVar}$ with connection through a separate switch [13-15].

The requirement of consumers of industrial enterprises to ensure a minimum deviation of the operating voltage from the nominal can also be satisfied by adjusting the power of the capacitor bank depending on the voltage $[1-4,16]$. In this case, capacitor banks, along with the main function of increasing the reactive power factor of the enterprise, are also used to regulate the voltage $[6-8,17]$.

During the hours of minimum load, when the voltage is high, the inclusion of capacitor banks leads to an excessive increase in voltage. Therefore, to maintain the rated voltage on the substation buses, the capacitor banks are disconnected when the voltage rises above the permissible value, and when the voltage decreases, they are turned on [6-9, 18].

In power supply systems for reactive power compensation, automated low-voltage installations with switching capacitor bank stages with special electro-mechanical contactors are also used [18-19].

The time interval of the step switching delay (on average about 60 seconds), due to the requirements of the standard for the discharge level of capacitor banks before reswitching and detuning from short-term fluctuations of reactive power in the compensated network, limits the use of these capacitor units for large groups of technological equipment (welding, lifting and transport, forging and press and others) [19-22].

Therefore, with a very variable inductive load, the socalled "dynamic compensation of reactive power" - Dynamic Power Factor Correction is used, i.e. compensation of reactive power in real time, significantly expanding the functionality of using capacitor banks, but requiring the installation of special types of semi-conductor starters and reactive power controllers [23].

In addition, the above installations have a number of disadvantages associated with the appearance of an arc at each switching, wear and sticking of contacts, noise during operation, as well as power losses in the coils of the contactors.

\section{Development of contactless device circuits}

Next, we analyze the operation of devices for automatic power control of compensating devices using contactless elements [1-3, 24-25].

In the world, scientific research is being carried out to improve reactive power regulators and improve the operational characteristics of contactless switching devices. At the same time, the creation of contactless devices for automatic control of the power of capacitor banks and switching various consumers operating in a high-voltage mode with frequent switching is considered one of the important tasks [3, 25-27].
We propose a scheme for automatic power control of capacitor banks directly as a function of the value of the reactive power factor, that is, the angle between the vectors of the supply network voltage and the load current. This method makes it possible to reduce the number of switching operations, since this angle changes significantly less than the value of the load current and supply voltage, which leads to an increase in the quality of work [26].

A diagram of one-stage power control of a capacitor bank as a function of angle $\varphi$ is shown in Fig. 1 .

The device consists of parallel-oppositely connected thyristors $T_{1}$ and $T_{2}$, a voltage relay $K V$, a current transformer with two secondary windings, a resistor $R$, diodes $D$ and additional resistances $R_{\mathrm{d}}$.

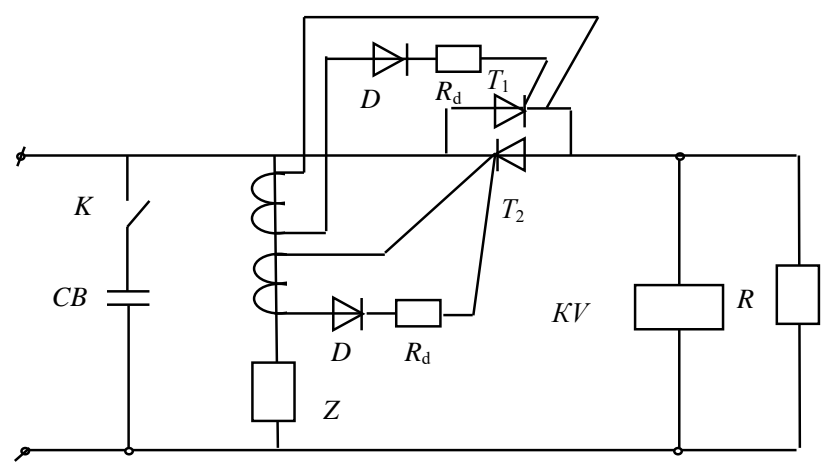

Fig.1. Capacitor bank power control circuit

The primary winding of the current transformer is connected in series with the load, and the secondary windings are connected to the control electrodes of the thyristors through diodes and resistors connected in series. A change in the value of the angle between the mains voltage and the load currents causes a change in the firing phase of the thyristors. The voltage across the resistor depends on the angle of the thyristors. With a decrease in the angle $\varphi$, the switching angle of the thyristors decreases and the voltage across the resistor $R$ increases and this causes the $K V$ relay to operate and disconnect the capacitor banks from the network [5, 12, 27].

Signals are fed to the control electrodes of the thyristors in the power capacitor circuit through a step-down transformer and a contactless voltage relay. The switching of three-phase capacitor banks as a function of voltage is carried out using two such relays, configured for different operating voltages [3, 28-29].

The choice of the elements of the considered voltage relay circuit was carried out taking into account the load power, the voltage of the secondary winding of the transformer, the operating and control currents of the thyristors [30].

To test the performance of the developed circuits of noncontact devices and to experimentally study the installations, prototypes of non-contact devices for regulating the power of capacitor banks were created [2, 6, 9, 30-31].

Experimental studies of the new device have shown that capacitor banks are connected to a single-phase network at a voltage of 140 Volts, and at a voltage of 190 Volts they are disconnected from the network.

The use of this device for contactless switching on and off of capacitor banks contributes to the optimal use of the capacity of the capacitor banks and the reduction of the reactive power deficit. In this case, a certain amount of electricity is saved. Regulation of the capacity of capacitor 
banks in industrial enterprises makes it possible to unload the system from reactive load [5, 9, 32-33].

Prototypes of such developments were tested in the laboratories of the Department of Power Supply of the Tashkent State Technical University.

\section{Experimental study of non-contact device circuits}

Automatic power regulators of capacitor banks, which depend on the value of the phase angle $\varphi$ and at the same time on the voltage across the load, make it possible to increase the reliability and improve the quality of operation of electrical devices, to reduce the weight and dimensions [3, $4,34]$.

Figures 2-6 show the characteristics of experimental studies of the device for automatic control of the power of capacitor banks in terms of the shift angle $\varphi$ and in voltage, which was created on the basis of the circuit shown in Fig.1.

For registration and processing of experimental data, a software-controlled apparatus "Fluke" was used. Curves of changes in current and voltage with a predominance of active load are shown in Fig.2.

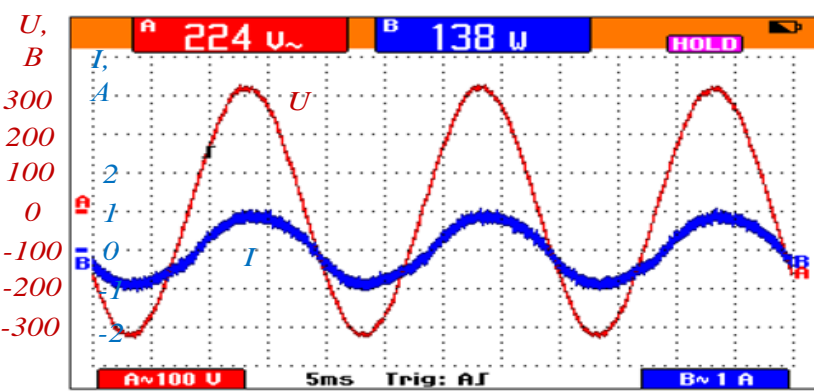

Fig.2. Curves of changes in current and voltage with an active nature of the load

In this case, at $U=224$ Volts, the values of the consumed active and reactive powers were, respectively, $138 \mathrm{~W}$ and 28 $\mathrm{VAr}$, and the value of the total power was $141 \mathrm{VA}$. Figure 3 shows the curves of current and voltage changes for the above case.

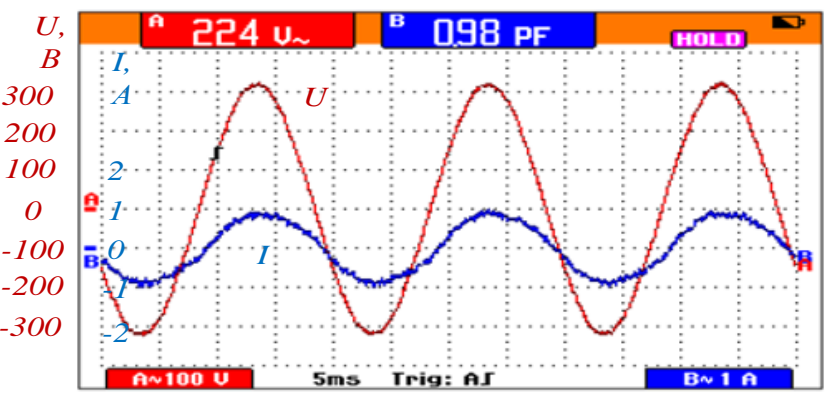

Fig.3. Curves of changes in current and voltage at $\cos \varphi=0,98$

In this operating mode, the opening angle of the thyristors is $13^{0}$ and the power factor is 0,98 [9]. Figures 3 and 4 show the curves of current and voltage changes, as well as the opening angle of the thyristors and the value of the power factor.

In this case, the power values $P=61 \mathrm{~W}, Q=34 \mathrm{VAR}$ and $S=70 \mathrm{VA}$, the value of the shift angle between the voltage and load current was $\varphi=300$ and $\cos \varphi=0.87$ [34].

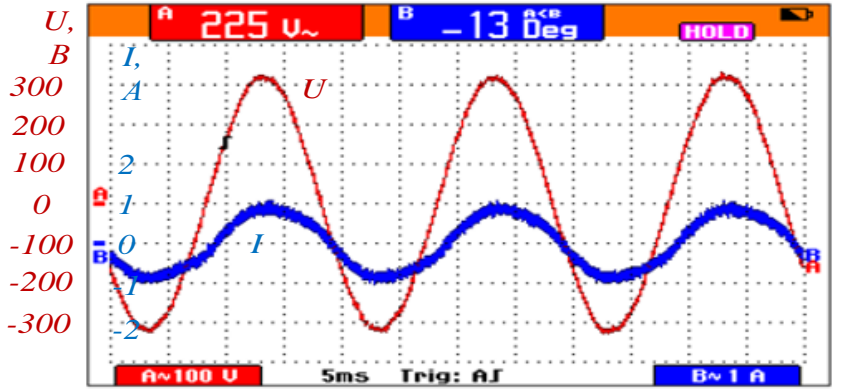

Fig.4. Curves of changes in current and voltage at $\varphi=13^{0}$

Figure 5 shows the curves of current and voltage changes with the capacitor banks turned on.

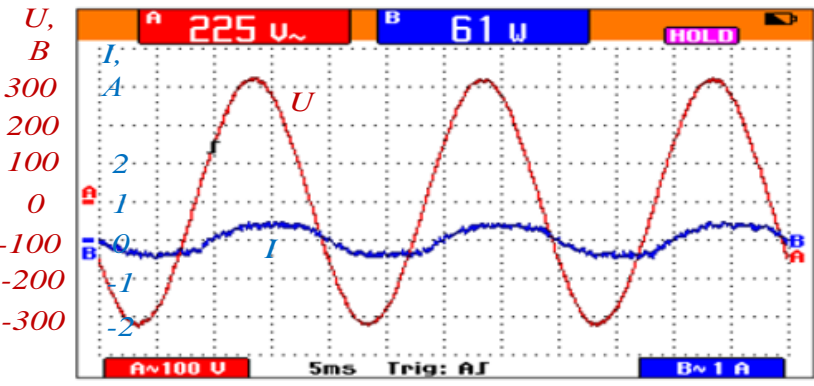

Fig.5. Curves of changes in current and voltage when the capacitor banks are turned on

With a decrease in the active load, the $\cos \varphi$ value decreeses accordingly to the device pickup value $(\cos \varphi<0,95)$. In this case, the contactless regulator automatically connects the capacitor banks to the network. Each capacitor bank has a capacity of $1 \mu \mathrm{F}$ for a voltage of $U=400 \mathrm{~V}$.

Further, the curves of the current and voltage changes in each phase were investigated during the switching on of the capacitor banks $[5,6,13,19,35-36]$.

Fig. 6 shows the changes in current and voltage in phase A when capacitor banks are switched on; in other phases, the curves are of a similar nature.

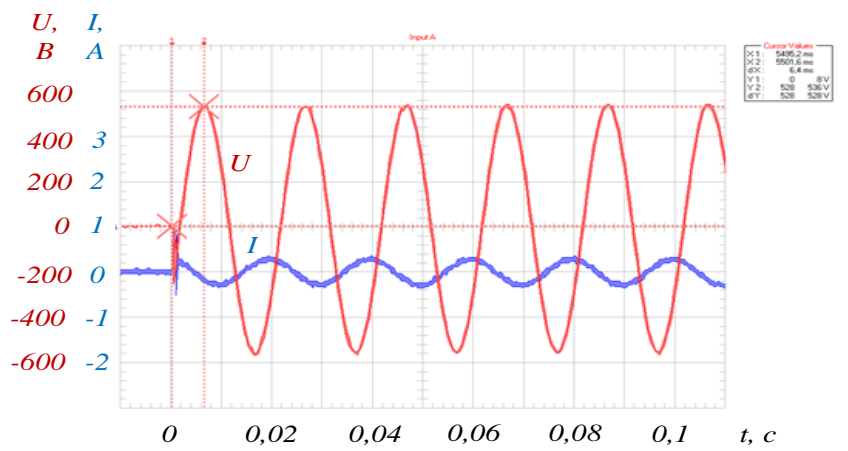

Fig.6. Curves of changes in current and voltage in phase A when the capacitor banks are turned on

\section{Conclusions}

1. For the first time, a circuit has been developed that makes it possible to experimentally investigate the characteristics of the circuit and the device for automatic power control of capacitor banks by the angle $\varphi$.

2. Investigations of the prototype of the contactless regulation of the capacitor banks' power in terms of voltage and load angle " $\varphi$ " showed that, while ensuring the full 
functioning of the prototype of the devices, it is distinguished by simplicity of control.

3. In parallel - the opposite switching on of thyristors, a change in the value of the angles between the mains voltage and the load current is caused by a change in the phase of firing of the thyristors. The voltage values on the control element depend on the angle of the thyristors.

4. The proposed method and circuit for automatic power control of capacitor banks, the function of the angle between the vectors of the mains voltage and the load current showed high reliability and ease of operation of the device.

5. A comprehensive study of structures, elements and automation circuits for regulating the power of capacitor banks made it possible to increase the possibilities of synthesizing new circuits, and also created conditions for improving the characteristics.

6. Experimental studies were carried out in laboratory and in production conditions of a prototype of a non-contact device for regulating the power of capacitor banks, and oscillograms of changes in voltage, current and other indicators were taken.

\section{References}

1. E.G.Usmanov, E.Kh.Abduraimov, R.Ch.Karimov. Using proximity relays to improve power quality (Journal "Bulletin of TSTU", Tashkent, Uzbekistan, 3-4, pp.48-51, 2012).

2. E.Usmanov, A.Rasulov, M.K.Bobojanov, R.Ch.Karimov. Non-contact voltage relay for switching windings of a boost transformer (E3S Web of Conferences, 139, 01079, 2019), https://doi.org/10.1051/e3sconf/201913901079

3. Yu.M.Kurbonov, and others. Analysis of the influence of temperature on the operating mode of a photovoltaic solar station (IOP Conference Series: Earth and Environmental Science, 614(1), 012034, 2020). doi:10.1088/17551315/614/1/012034

4. K.B.Nazirov, S.D.Dzhuraev, and others. Simulation of the Municipal-Household Electrical Supply System for Calculation and Forecasting the Level Current and Voltage Higher Harmonics (Proceedings of the 2020 IEEE Conference of Russian Young Researchers in Electrical and Electronic Engineering, EIConRus 2020, pp.1276-1281, 9038935, 2020). DOI: 10.1109/EIConRus49466.2020.9038935

5. Karimov R.Ch., Bobojanov M.K., Rasulov A.N., Usmanov E.G. Controlled switching circuits based on non-linear resistive elements (E3S Web of Conferences, 139, 01039, 2019), https://doi.org/10.1051/e3sconf/201913901039

6. E.B.Saitov. Optimal model for additional operation of the storage system for photovoltaic wind power plants (E3S Web of Conferences, 220, 01080, 2020). https://doi.org/10.1051/e3sconf/202022001080

7. R.Karimov, and others. Modeling of kinematics and kinetostatics of planetary-lever mechanism (IOP Conference Series: Materials Science and Engineering, 883(1), 012129, 2020). doi:10.1088/1757-899X/883/1/012129

8. E.B.Saitov, and others. Study of Solar Radiation and Wind Characteristics in Various Regions of Uzbekistan (E3S Web of Conferences, 220, 01061, 2020). DOI: 10.1051/e3sconf/202022001061

9. R.Karimov, and others. Reliability indicators of stabilizing devices in the agriculture electrical supply system (IOP Conf.
Series: Materials Science and Engineering, 883(1), 012142, 2020). doi:10.1088/1757-899X/883/1/012142

10. E.B.Saitov. Renewable Energy Development in Uzb.: Current Status, Problems and Solutions (E3S Web of Conf., 216, 01134, 2020). DOI: 10.1051/e3sconf/202021601134

11. R.Karimov, and others. Non-contact controlled voltage stabilizer for power supply of household consumers (IOP Conf. Series: Materials Science and Engineering, 883(1), 012120, 2020). doi:10.1088/1757-899X/883/1/012120

12. S.Shoguchkarov, and others. The effect of the surface geometry of a photovoltaic battery on its efficiency (E3S Web of Conferences, 216, 01149, 2020). https://doi.org/10.1051/e3sconf/202021601149

13. K.B.Nazirov, Z.S.Ganiev, S.D.Dzhuraev, and others. Measurement of Emissions of High Harmonic Currents in Modern Electrical Receiver in Municipal-Households Power Supply System (Proceedings of the 2020 IEEE Conference of Russian Young Researchers in Electrical and Electronic Engineering, EIConRus 2020, pp.1270-1275, 9039148, 2020). DOI: 10.1109/EIConRus49466.2020.9039148

14. R.Karimov, M.Bobojanov. Analysis of voltage stabilizers and non-contact relays in power supply systems (E3S Web of Conferences, 216, 01162, 2020). https://doi.org/10.1051/e3sconf/202021601162

15. K.B.Nazirov, Z.S.Ganiev, S.D.Dzhuraev, and others. Elaboration of the Method for Providing the Level of Power Quality in the Nodes of the Energy System while Power Quality Monitoring (Proceedings of the 2020 IEEE Conf. of Russian Young Researchers in Electrical and Electronic Engineering, EIConRus 2020, pp.1282-1286, 9039416 , 2020). DOI: 10.1109/EIConRus49466.2020.9039416

16. E.B.Saitov, and others. Networked interactive solar panels over the roof photovoltaic system (PVS) and its cost analysis at TSTU (E3S Web of Conferences, 216, 01133, 2020). https://doi.org/10.1051/e3sconf/202021601133

17. R.Karimov. Study of the state of the issue of increasing the quality of electric energy in the power supply systems (E3S Web of Conferences, 216, 01163, 2020). https://doi.org/10.1051/e3sconf/202021601163

18. I.Sapaev, and others. Matlab-model of a solar photovoltaic station integrated with a local electrical network (IOP Conference Series: Materials Science and Engineering, 883, 012116, 2020). doi:10.1088/1757-899X/883/1/012116

19. Karimov R.Ch. Using optoelectronic noncontact voltage relay in electrical supply systems (Technical science and innovation, 2, 2019). uzjournals.edu.uz/btstu/vol2019/iss2/8 20. J.Toshov, E.Saitov. Portable autonomous solar power plant for individual use (E3S Web of Conferences, 139, 01087, 2019) https://doi.org/10.1051/e3sconf/201913901087 21. S.D.Dzhuraev, S.M.Sultonov, and others. Compensation of Higher Harmonics of Current in the Electric Power Systems Containing Loads with Nonlinear Volt-Ampere Characteristics (Proceedings of the 2020 IEEE Conference of Russian Young Researchers in Electrical and Electronic Engineering, EIConRus 2020, pp.1208-1213, 9039016, 2020). DOI: 10.1109/EIConRus49466.2020.9039016

22. B.D.Inoyatov, A.Raseel, V.N.Tulsky, S.D.Dzhuraev. Power quality monitoring as a tool for phase conductors diagnostics (Proceedings of the 2019 IEEE Conference of Russian Young Researchers in Electrical and Electronic Engineering, ElConRus 2019, pp.973-976, 8656913, 2019). DOI: 10.1109/EIConRus.2019.8656913 
23. Bakhadyrkhanov M.K., and others. Silicon Photovoltaic Cells with Clusters of Nickel Atoms (Applied Solar Energy "English translation of Geliotekhnika", 52(4), pp.278-281, 2016) https://doi.org/10.3103/S0003701X1604006X

24. Rasulov A.N., Karimov R.Ch. The Contactless Relay of Tension in System of Power Supply (EESJ, 4, pp.174-178, 2015), doi:10.12851/EESJ201508C05ART02

25. I.U.Rakhmonov, K.M.Reymov. Statistical models of renewable energy intermittency // RSES 2020. E3S Web of Conferences. $\quad 216 \quad 01167$. https://doi.org/10.1051/e3sconf/202021601167

26. I.U.Rakhmonov, N.N.Kurbonov. Analysis of automated software for monitoring energy consumption and efficiency of industrial enterprises // E3S Web of Conferences. 216 (2020) 01178. https://doi.org/10.1051/e3sconf/202021601178 27. F.A.Hoshimov, I.U.Rakhmonov, N.N.Niyozov. Technology to reduce energy costs in the electric steel melting shop // ENERGY-21. E3S Web of Conferences. 209 (2020) 07017. https://doi.org/10.1051/e3sconf/202020907017 28. Rasulov A.N., Karimov R.Ch. The Contactless Thyristor Device for Inclusion and Shutdown of Condenser Installations in System of Power Supply (EESJ, 4, pp.179-183, 2015). doi:10.12851/EESJ201508C05ART01

29. Bobojanov M.K., and others. Study of the efficiency of conveyors of mining transport systems of mining complexes (E3S Web of Conferences, 177, 03023, 2020). https://doi.org/10.1051/e3sconf/202017703023

30. Rasulov A.N., and others. Graphical-analytical method for constructing load characteristics (E3S Web of Conf. 216, 01171, 2020). https://doi.org/10.1051/e3sconf/202021601171 31. S.D.Dzhuraev, and others. Calculation of Permissible Power of Synchronous Generators Functioning with Transformer Load (Power Technology and Engineering, 2018, 52(4), pp.466-473, 2018). DOI: 10.1007/s10749-018-0976-3 32. S.D.Dzhuraev, and others. Effect of additional capacities on transients recovery voltage in the short - Line - Fault regime (Proceedings of the 2019 IEEE Conference of Russian Young Researchers in Electrical and Electronic Engineering, ElConRus 2019, pp.1044-1046, 8657006, 2019). DOI: 10.1109/EIConRus.2019.8657006

33. S.D.Dzhuraev, and others. Study of the operating modes of the $0.4 \mathrm{kV}$ main distribution network, in Dushanbe city of the Republic of Tajikistan, with distributed solar generation for power losses and power quality estimation (Proceedings of the 2018 IEEE Conference of Russian Young Researchers in Electrical and Electronic Engineering, ElConRus 2018, pp.737-742, 2018). DOI: 10.1109/EIConRus.2018.8317197

34. S.D.Dzhuraev, and others. Study and analysis of power quality of electric power system. Case study: Republic of Tajikistan (Proceedings of the 2018 IEEE Conf. of Russian Young Researchers in Electrical and Electronic Engineering, pp.827-833, 2018). DOI: 10.1109/EIConRus.2018.8317217

35. S.D.Dzhuraev, and others. Analysis of the results of higher harmonic modeling in the electric networks of the Republic of Taj. with various voltage levels (Proceedings of the 2018 IEEE Conference of Russian Young Researchers in Electrical and Electronic Engineering, ElConRus 2018, pp.611-616, 2018). DOI: 10.1109/EIConRus.2018.8317171

36. Korovkin N., and others. Development of Energy Systems Planning Methods (E3S Web of Conferences, 209, 02005, 2020). DOI: 10.1051/e3sconf/202020902005. 